\title{
Environmental Toxin Screening Using Human-Derived 3D Bioengineered Liver and Cardiac Organoids
}

\author{
Steven D. Forsythe ${ }^{1}$, Mahesh Devarasetty ${ }^{1}$, Thomas Shupe ${ }^{1}$, Colin Bishop ${ }^{1}$, \\ Anthony Atala ${ }^{1,2}$, Shay Soker ${ }^{1,2,3,4}$ and Aleksander Skardal ${ }^{1,2,3,4 *}$
}

' Wake Forest School of Medicine, Wake Forest Institute for Regenerative Medicine, Medical Center, Winston-Salem, NC, United States, ${ }^{2}$ Virginia Tech-Wake Forest School of Biomedical Engineering and Sciences, Wake Forest School of Medicine, Medical Center Boulevard, Winston-Salem, NC, United States, ${ }^{3}$ Comprehensive Cancer Center at Wake Forest Baptist Medical, Medical Center Boulevard, Winston-Salem, NC, United States, ${ }^{4}$ Department of Cancer Biology, Wake Forest School of Medicine, Medical Center Boulevard, Winston-Salem, NC, United States

OPEN ACCESS

Edited by: Alexander Kinev, Creative Scientist, United States

Reviewed by: Charalampos Socrates Siristatidis, National and Kapodistrian University of Athens, Greece Harini Bathulapalli, Yale University, United States

${ }^{*}$ Correspondence:

Aleksander Skardal askardal@wakehealth.edu

Specialty section: This article was submitted to Epidemiology, a section of the journal Frontiers in Public Health

Received: 20 December 2017 Accepted: 26 March 2018 Published: 16 April 2018

Citation:

Forsythe SD, Devarasetty $M$ Shupe T, Bishop C, Atala A, Soker S and Skardal A (2018) Environmental

Toxin Screening Using HumanDerived 3D Bioengineered Liver and Cardiac Organoids.

Front. Public Health 6:103. doi: 10.3389/fpubh.2018.00103
Introduction: Environmental toxins, such as lead and other heavy metals, pesticides, and other compounds, represent a significant health concern within the USA and around the world. Even in the twenty-first century, a plethora of cities and towns in the U.S. have suffered from exposures to lead in drinking water or other heavy metals in food or the earth, while there is a high possibility of further places to suffer such exposures in the near future.

Methods: We employed bioengineered 3D human liver and cardiac organoids to screen a panel of environmental toxins (lead, mercury, thallium, and glyphosate), and charted the response of the organoids to these compounds. Liver and cardiac organoids were exposed to lead (10 $\mu \mathrm{M}-10 \mathrm{mM})$, mercury (200 nM-200 $\mu \mathrm{M})$, thallium (10 nM-10 $\mu \mathrm{M})$, or glyphosate $(25 \mu \mathrm{M}-25 \mathrm{mM})$ for a duration of $48 \mathrm{~h}$. The impacts of toxin exposure were then assessed by LIVE/DEAD viability and cytotoxicity staining, measuring ATP activity and determining IC50 values, and determining changes in cardiac organoid beating activity.

Results: As expected, all of the toxins induced toxicity in the organoids. Both ATP and LIVE/DEAD assays showed toxicity in both liver and cardiac organoids. In particular, thallium was the most toxic, with IC50 values of 13.5 and $1.35 \mu \mathrm{M}$ in liver and cardiac organoids, respectively. Conversely, glyphosate was the least toxic of the four compounds, with IC50 values of 10.53 and $10.85 \mathrm{mM}$ in liver and cardiac organoids, respectively. Additionally, toxins had a negative influence on cardiac organoid beating activity as well. Thallium resulting in the most significant decreases in beating rate, followed by mercury, then glyphosate, and finally, lead. These results suggest that the 3D organoids have significant utility to be deployed in additional toxicity screening applications, and future development of treatments to mitigate exposures.

Conclusion: 3D organoids have significant utility to be deployed in additional toxicity screening applications, such as future development of treatments to mitigate exposures, drug screening, and environmental toxin detection.

Keywords: tissue engineering and regenerative medicine, organoids, environmental toxins, hepatocytes, cardiomyocytes, three dimensional 


\section{INTRODUCTION}

Environmental toxins continue to represent a significant health concern within the United States and around the world. Even in the twenty-first century, we continue to hear of cities and towns in the U.S. have suffered from exposures to lead in drinking water and other heavy metals in food or the earth $(1,2)$. Moreover, there is equal potential for other locations to suffer such exposures in the future due to possible deregulation of those government agency policies that manage environmental toxins and other compounds.

Environmental heavy metals have long been known to cause cell and tissue damage, often leading to major health complications, especially in children (3). Exposure to heavy metals has been implicated in a host of gastrointestinal, hepatic, cardiac, and neurological disorders, including autism spectrum disorder (4). Increasing industrial and agricultural uses for heavy metals over the span of many years have led to an exponential increase in the concentration of these materials in soil and water, and subsequently in a variety of food sources, resulting in passage to humans through a number of methods, including consumption, inhalation, and direct skin contact $(4,5)$. Within the human body, environmental heavy metals have been demonstrated to affect the functionality of cell organelles, lipid membranes, and cytoplasmic enzymes. Additionally, heavy metals are able to interact directly with nucleic acids and nuclear proteins resulting in DNA damage leading to altered cell function, cancer, and cell death $(6,7)$. In addition to heavy metals, some compounds in pesticides have been determined to cause toxic effects in humans and wildlife, with many becoming banned due to these consequences, the most famous being DDT $(8,9)$. In addition to cases of acute toxicity, possible negative chronic afflictions on exposed populations include cancers, diabetes, endocrine disruption, neurodegenerative diseases, and potential epigenetic changes (10-15).

In the context of environmental toxin research, few if any significant studies have employed truly human-representative microphysiological systems $(16,17)$, such as 3D organoids or bioengineered tissue constructs, to assess the effects of environmental toxins on human physiology. Many studies do exist that employ traditional 2D cull cultures or animal studies, neither of which is necessarily completely representative of human physiology or human response to drugs and other compounds. Despite useful for many areas of research, animal models allow limited manipulation and deep study of biological mechanisms at play (18). On the other hand, traditional in vitro $2 \mathrm{D}$ cultures fail to recapitulate the 3D microenvironment of in vivo tissues (19). Drug diffusion kinetics vary dramatically, drug doses effective in 2D are often ineffective when scaled to animals or human patients, and cell-cell/cell-matrix interactions are inaccurate $(20,21)$. Moreover, the very nature of $2 \mathrm{D}$ versus $3 \mathrm{D}$ environments can significantly impact cellular behavior and phenotype. For example, in studies on cancer and mimicking the tumor microenvironment, our group recently demonstrated that on $2 \mathrm{D}$ tissue culture dishes, metastatic cancer cells appeared epithelial, not malignant, but when transitioned into a 3D tissue organoid environment they "switched" to a more accurate mesenchymal and metastatic phenotype $(22,23)$. Such 3D models have rapidly gained favor in areas, such as cancer and drug development, yet deployment for applications such as environmental toxin research has lagged as few examples exist in the literature. Yet $3 \mathrm{D}$ organoids could be valuable tools in environmental toxicity and safety research. These types of technologies could be used for a variety of applications, ranging from diagnostic testing of materials collected in field studies to development of treatment regimens-such as chelation therapies in the case of some heavy metal exposures-that can be used in human patients.

Our group has developed 3D organoids for multiple organs with human-like physiological function consisting of either primary cell or induced pluriopotent stem (iPS) cell origin for the purpose of testing compounds for efficacy and safety. Notably, these organoids are comprised of representative cell populations from their in vivo counterparts, can be maintained with high viability for long periods of time, are metabolically active, and respond to and metabolize drugs accurately $(24,25)$. Here, we describe the utilization of these organoids for the testing of environmental toxins on two organs often implicated in environmental toxicity-cardiac and liver. We performed a series of tests to assess the negative effects on both cardiac and liver organoids for each environmental toxin, including three heavy metals and one pesticide active component, with the rationale of creating a $3 \mathrm{D}$ in vitro system with a high similarity toward the parent tissue. Our results suggest the utility of our system allows for rapid testing of potential environmental hazards with the ability to induce large-scale reproducibility and find precise estimation of toxicity levels in multiple organ systems.

\section{MATERIALS AND METHODS}

No human subjects were employed in the described studies, as all cells were purchased commercially. Additionally, all experiments involving biohazards, select agents, and toxins were performed in line with institutional safety guidelines of Wake Forest Baptist Medical Center.

\section{Liver and Cardiac Cell Sources, Culture, and Organoid Formation}

For liver organoids, all cells used were commercially sourced, human primary cells. Hepatic stellate cells (HSCs) (ScienCell, Carlsbad, CA, USA) were expanded in culture for two passages before cryopreservation for use in organoid formation. During expansion, HSCs were cultured in 90\% high glucose DMEM (Thermo Fisher, Waltham, MA, USA) and 10\% fetal bovine serum (Atlanta Biologicals, Flowery Branch, GA, USA) on a rat tail collagen I coating $\left(10 \mathrm{~g} / \mathrm{cm}^{2}\right.$, Corning, Corning, NY, USA) at $37^{\circ} \mathrm{C}$ with $5 \% \mathrm{CO}_{2}$ primary human hepatocytes (Triangle Research Labs, RTP, NC) were thawed according to manufacturer instructions using hepatocyte thawing medium (Triangle Research Labs). Kupffer cells were also thawed via manufacturer instructions (Gibco, Waltham, MA, USA). Primary human hepatocytes (Triangle Research Labs) were thawed as mentioned above, then plated on collagen coated (10 g/ $\mathrm{cm}^{2}$, Corning) 6-well culture plates, using hepatocyte plating medium (Triangle Research Labs) at a density of $\sim 150,000$ cells $/ \mathrm{cm}^{2}$. Cells were incubated at $37^{\circ} \mathrm{C}$ 
with $5 \% \mathrm{CO}_{2}$ for $4 \mathrm{~h}$ before adding matrigel as an overlay (BD Biosciences, San Jose, CA, USA). Following further incubation for $24 \mathrm{~h}$, fresh HCM medium (Lonza, Walkersville, MD, USA) was added.

For cardiac organoids, induced pluripotent stem cell-derived cardiomyocytes (iPSC CMs) were commercially sourced from Axiogenesis (cat. \#COR.4U Cardiomyocytes). Human primary cardiac fibroblasts were commercially sourced from ScienCell (cat. \#6330). Prior to organoid formation, iPSC CMs were cultured on tissue culture plastic for $48 \mathrm{~h}$ in COR.4U medium until cells began beating spontaneously. At this point, iPSC CMs were harvested using trypsin-EDTA (Hyclone, Logan, UT).

The liver cells were combined in a cell seeding mixture comprised of $90 \%$ HCM medium (Lonza), 10\% heat-inactivated fetal bovine serum (Gibco), and rat tail collagen I (10 ng/ $\mu \mathrm{l}$, Corning). Liver organoids were produced with a mixture of $80 \%$ hepatocytes (Triangle Research Labs), 10\% hepatic stellate cells (ScienCell), and 10\% Kupffer cells (Gibco). Approximately 1,500 cells per $40 \mu \mathrm{L}$ media were used to form aggregates in each well of a non-adherent, round-bottom, 96-well plates to produce spherical organoids (\#7007, Corning). Cardiac organoids were produced similarly. IPSC CMs were suspended in cardiomyocyte maintenance medium (CMM, Stem Cell Theranostics, Redwood City, CA, USA). Fibroblasts were added as $10 \%$ of the total cell number, and the volume was adjusted to reach a cell density of 10,000 cells/mL. $100 \mu \mathrm{L}$ of cell suspension was pipetted into each well of a non-adherent, round-bottom, 96-well plates to produce spherical organoids resulting in approximately 1,000 cells/ organoid. Well plates were incubated and observed daily until organoid formation, and then immediately used in experiments.

\section{Preparation of Drug Stock Solutions}

All four compounds were purchased from Sigma Aldrich (St. Louis, MO, USA). Drugs were dissolved in $\mathrm{DI} \mathrm{H}_{2} \mathrm{O}$ for

TABLE 1 | Summary of the effects of the environmental toxins on liver spheroids.

\begin{tabular}{lccc}
\hline $\begin{array}{l}\text { Environmental toxins } \\
\text { on liver organoids }\end{array}$ & $\begin{array}{c}\text { Range of } \\
\text { doses }\end{array}$ & $\begin{array}{c}\text { Live/dead } \\
\text { effective dose }\end{array}$ & ATP IC50 \\
\hline Glyphosate & $25 \mu \mathrm{M}-25 \mathrm{mM}$ & $250 \mu \mathrm{M}-2.5 \mathrm{mM}$ & $10.53 \mathrm{mM}$ \\
Lead & $10 \mu \mathrm{M}-10 \mathrm{mM}$ & $100 \mu \mathrm{M}-1 \mathrm{mM}$ & $2.98 \mathrm{mM}$ \\
Mercury & $200 \mathrm{nM}-200 \mu \mathrm{M}$ & $2-20 \mu \mathrm{M}$ & $30.8 \mu \mathrm{M}$ \\
Thallium & $10 \mathrm{nM}-10 \mu \mathrm{M}$ & $1-10 \mu \mathrm{M}$ & $13.5 \mu \mathrm{M}$
\end{tabular}

Effective dose for live/dead imaging is summarized as a qualitative measure of rapid cell death detected in images. environmental toxins to reach $20 \mathrm{mM}$ concentration for lead (II) chloride (203572), $10 \mathrm{mM}$ for mercury (II) chloride (215465), and thallium nitrate (204609), and $50 \mathrm{mM}$ concentration for glyphosate (45521), respectively. Doses were taken from previous research on toxicity in model systems and experiments were performed to determine an IC50 cellular activity for ATP assay. Serial dilutions were performed in media for each cell type until all concentrations were created at $2 \mathrm{X}$ final concentration. Specifically, lead was assessed at $10 \mu \mathrm{M}-10 \mathrm{mM}$; mercury was assessed at $200 \mathrm{nM}-200 \mu \mathrm{M}$; thallium was assessed at $10 \mathrm{nM}-100 \mu \mathrm{M}$; and glyphosate was assessed at $25 \mu \mathrm{M}-25 \mathrm{mM}$ (Tables 1 and 2).

\section{Live/Dead Staining}

Organoids were isolated from 96 -well low adhesion round bottom plates, suspended in Hystem hydrogel (GS311, ESI BIO, Alameida, CA, USA) in a $20 \mu \mathrm{L}$ construct, and placed into 12 -well plates to immobilize organoids in a $3 \mathrm{D}$ extracellular matrix environment, as we have described previously $(24,26,27)$. Each concentration of environmental toxin premixed at $1 \mathrm{X}$ concentration in media according to organoid type was added to individual wells and organoids were allowed to incubate under their respective conditions for 2 days at $37^{\circ} \mathrm{C}$ with $5 \% \mathrm{CO}_{2}$. Studies were performed using $n=5$ or higher for all conditions. Media was then removed and organoids were assessed by LIVE/DEAD ${ }^{\circledR}$ Viability/Cytotoxicity Kit assays (Invitrogen, Carlsbad, CA, USA). Specifically, $2.0 \mu \mathrm{M}$ calcein AM and 4.0 $\mu \mathrm{M}$ ethidium homodimer in PBS was added to each well and was allowed to incubate for $1 \mathrm{~h}$. Imaging was then performed by macro-confocal microscopy (Leica TCS LSI, Leica, Wetzlar, Germany) and composite images were created with ethidium bromide red fluorescence representing dead nuclei and calcein AM green fluorescence representing live cells.

\section{ATP Activity Assays}

Environmental toxins were added in a premix $2 \times$ concentration of $100 \mu \mathrm{L}$ solution to each well of a 96-well plate containing an organoid with $100 \mu \mathrm{L}$ of media and allowed to incubate for 2 days at $37^{\circ} \mathrm{C}$ with $5 \% \mathrm{CO}_{2}$ with $n=6$ or higher. Media was then removed from each well leaving $100 \mu \mathrm{L}$ of media remaining along with the organoid. Next, $100 \mu \mathrm{L}$ of Cell-Titer Glo Luminescent Cell Viability Assay solution, prepared according to maufacturer's instructions (G7571, Promega, Madison, WI, USA), was added to each well along with $100 \mu \mathrm{L}$ added to $100 \mu \mathrm{L}$ DMEM in a Costar Black Polystrene 96-well assay plate and allowed to incubate for $10 \mathrm{~min}$ at room temperature shielded from light. The entire contents of the wells containing organoids were then added to

TABLE 2 | Summary of the effects of the environmental toxins on cardiac spheroids.

\begin{tabular}{|c|c|c|c|c|c|c|}
\hline $\begin{array}{l}\text { Environmental toxins on } \\
\text { cardiac organoids }\end{array}$ & $\begin{array}{l}\text { Range of } \\
\text { Doses }\end{array}$ & $\begin{array}{l}\text { Live/Dead } \\
\text { Effective Dose }\end{array}$ & IC50 & $\begin{array}{l}\text { Heart beat effective } \\
\text { dose at } 30 \mathrm{~min}\end{array}$ & $\begin{array}{l}\text { Heart beat effective } \\
\text { dose at } 24 \mathrm{~h}\end{array}$ & $\begin{array}{l}\text { Heart beat effective } \\
\text { dose at } 48 \mathrm{~h}\end{array}$ \\
\hline Glyphosate & $25 \mu \mathrm{M}-25 \mathrm{mM}$ & $2.5-25 \mathrm{mM}$ & $10.85 \mathrm{mM}$ & $2.5 \mathrm{mM}$ & $2.5 \mathrm{mM}$ & $2.5 \mathrm{mM}$ \\
\hline Mercury & $200 \mathrm{nM}-200 \mu \mathrm{M}$ & $2-20 \mu \mathrm{M}$ & $44 \mu \mathrm{M}$ & $2 \mu \mathrm{M}$ & $2 \mu \mathrm{M}$ & $2 \mu \mathrm{M}$ \\
\hline Thallium & $10 \mathrm{nM}-10 \mu \mathrm{M}$ & $10-100 \mu \mathrm{M}$ & $1.35 \mu \mathrm{M}$ & $10 \mu \mathrm{M}$ & $1 \mu \mathrm{M}$ & $1 \mu \mathrm{M}$ \\
\hline
\end{tabular}

Effective dose for live/dead imaging is summarized as a qualitative measure of rapid cell death detected in images. Effective dose for heart beat assay at each time point is described by a $p$-value of 0.05 . 
Costar Black Polystrene 96-well assay plate wells and the contents were read on a Vertias Microplate Luminometer using default settings. Values were then averaged among the different groups and graphed for analysis using Graph Pad Prism@ $@$ software.

\section{Heart Beat Assay}

Fully formed cardiac organoids in the wells of a 96-well nonadhesive round bottom plate were placed under a Leica DMIL LED microscope to allow for the recording of natural beat rates in $20 \mathrm{~s}$ videos $(n=3)$. The plate was then returned to the $37^{\circ} \mathrm{C}, 5 \% \mathrm{CO}_{2}$ incubator for $5 \mathrm{~min}$ to ensure that organoids did not experience significant temperature decreases, which can detrimentally impact beating rates. The process was repeated until all experimental subject organoids under the compound concentrations described above, but at varying time points, had been recorded. Environmental toxins were added as $2 \times 100 \mu \mathrm{L}$ concentration to each well of a 96-well low adhesion round bottom plate containing $100 \mu \mathrm{L}$ of normal media with a cardiac spheroid, and allowed to incubate for $30 \mathrm{~min}$ at $37^{\circ} \mathrm{C}$. The plate was then recorded, 3 organoids at a time, in the process listed above until all organoids were recorded and the plate was returned to the incubator. The process was then repeated 24 and $48 \mathrm{~h}$ later. The $20 \mathrm{~s}$ videos were then analyzed: beats were counted for each video and multiplied by 3 to scale values to beats per minute. A beat was defined as the beginning of the contractile movement of the organoid. A beat did not need reach conclusion to be counted. If multiple beating regions were observed then the beating of the largest multi-cell structure was used to calculate the beating rate.

\section{Statistical Analysis}

The data are generally presented as the means of number of replicates \pm SD. All data are graphed and analyzed for significance using a Student's T-test. For ATP activity assays $p$-values were considered significant under 0.01 . For beating kinetic assays $p$-values were considered significant under 0.05. Data samples were eliminated from the experimental groups if they fell outside of two SDs from the experimental group averages. Sample sizes (generally $n=5$ or $n=6$, depending on the experiment as described) were determined based on preliminary experiments. These sample sizes, with the typically observed SDs, allowed statistical significance at $\alpha=0.05$ with statistical power greater than $80 \%$.

\section{RESULTS}

\section{Organoid Production and Viability}

Liver organoids successfully formed at 4 days, with cardiac organoids taking 7 days to allow for self-propagating beating to occur. Viability for both was confirmed to be high (greater than 95\%) via live/dead imaging (Figures $\mathbf{1}$ and 2, top left panel).

\section{Environmental Toxins}

Dissolution of the environmental toxins was performed in the presence of $\mathrm{DIH}_{2} \mathrm{O}$ due to previous research in toxin testing (28-30). Mercury (II) chloride $\left(254.19 \mathrm{mM}\right.$ at $\left.20^{\circ} \mathrm{C}_{2} \mathrm{O}\right)$ and thallium (I) nitrate $\left(358.51 \mathrm{mM}\right.$ at $\left.20^{\circ} \mathrm{C}_{2} \mathrm{O}\right)$ dissolved readily in $\mathrm{DIH}_{2} \mathrm{O}$ and remained dissolved with no precipitation during storage. Glyphosate $\left(70.98 \mathrm{mM}\right.$ at $\left.25^{\circ} \mathrm{C}_{2} \mathrm{O}\right)$ did not dissolve readily until constant stirring and heat was applied, it remained dissolved at $25 \mathrm{mM}$ in $\mathrm{DIH}_{2} \mathrm{O}$ with no precipitation after storage. Lead (II) chloride dissolved readily in $\mathrm{DIH}_{2} \mathrm{O}$ at $20 \mathrm{mM}\left(35.60 \mathrm{mM}\right.$ at $20^{\circ} \mathrm{C}$ $\mathrm{H}_{2} \mathrm{O}$ ); however, after addition to media to create $10 \mathrm{mM}$ treatment some precipitate was observed, although this precipitate did not occlude LIVE/DEAD imaging.

\section{Organoid Viability Following Toxin Exposure}

Live/dead staining of liver organoids (Figure 1) was used to visualize indications of cytotoxicity due to toxin exposure. Organoid integrity and viability begins to show a steady reduction at doses of $250 \mu \mathrm{M}$ to $2.5 \mathrm{mM}$ for glyphosate (11 mM ATP IC50), 1-10 mM for lead (2.5 mM ATP IC50), 2-20 $\mu \mathrm{M}$ for mercury (33 $\mu \mathrm{M}$ ATP IC50), and $1-10 \mu \mathrm{M}$ for thallium $(18 \mu \mathrm{M}$ ATP IC50). Cardiac organoid responses (Figure 2) tended to occur at higher doses than displayed for liver and were more in line with IC50's revealed by ATP testing, described below. The organoids maintained integrity during all testing, but cell death occurred between doses of 2.5 and $25 \mathrm{mM}$ for glyphosate $(12.1 \mathrm{mM}$ for ATP IC50), 1 and $10 \mathrm{mM}$ for lead (2.2 mM for ATP IC50), 20 and $200 \mu \mathrm{M}$ for mercury (37.4 $\mu \mathrm{M}$ for ATP IC50), and between 10 and $100 \mu \mathrm{M}$ for thallium ( $1 \mu \mathrm{M}$ for ATP IC50).

\section{Effects of Toxin Exposure on Organoid ATP Activity}

ATP activity test in this experiment was designed to determine the dose for IC50 value for each of the environmental toxins on primary liver (Figure 3) and cardiac (Figure 4) organoids and are summarized in Tables $\mathbf{1}$ and 2. After testing original three doses $(n \geq 6)$ for each toxin centered on doses described in the literature $(28,29)$, two further trials narrowed the range containing the IC50. IC50 was calculated using the Graph Pad Prism (C) software. IC50 numbers were similar for cardiac and liver for three of the drugs: glyphosate $(10.85,10.53 \mathrm{mM})$, lead $(2.45,2.98 \mathrm{mM})$, and mercury $(44,30.8 \mu \mathrm{M})$, respectively. Thallium toxicity was determined as 1.35 and $13.5 \mu \mathrm{M}$ for liver and cardiac, respectively. For liver organoids, the following conditions resulted in statistically significant decreases in ATP activity $(p<0.001)$ : $10 \mathrm{mM}$ glyphosate, $2.5 \mathrm{mM}$ lead, $20 \mu \mathrm{M}$ mercury, $5 \mu \mathrm{M}$ thallium, and higher concentrations. For cardiac organoids, the following conditions resulted in statistically significant decreases in ATP activity $(p<0.001): 5 \mathrm{mM}$ glyphosate, $2.5 \mathrm{mM}$ lead, $50 \mu \mathrm{M}$ mercury, $1 \mu \mathrm{M}$ thallium, and higher concentrations. Significant $p$-values were detected at higher than control value for the lowest values of mercury doses tested, 2 and $10 \mu \mathrm{M}$, reflecting results observed for heartbeat assay with an increase at $20 \mu \mathrm{M}$ short term (Figure 4C).

\section{Toxin Exposures Decrease Cardiac Organoid Beating Rates}

Time points to test physiological reactions to environmental toxins were chosen based on previous studies testing calcium 

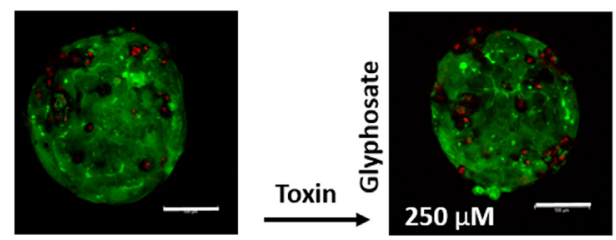

Healthy Liver Organoid
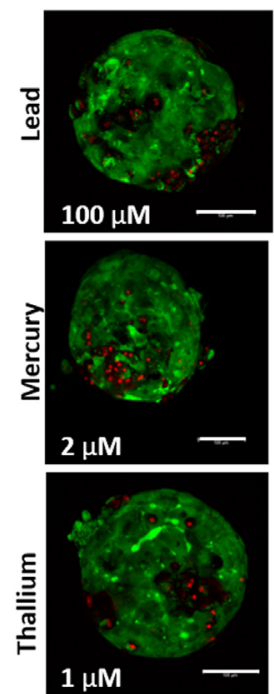
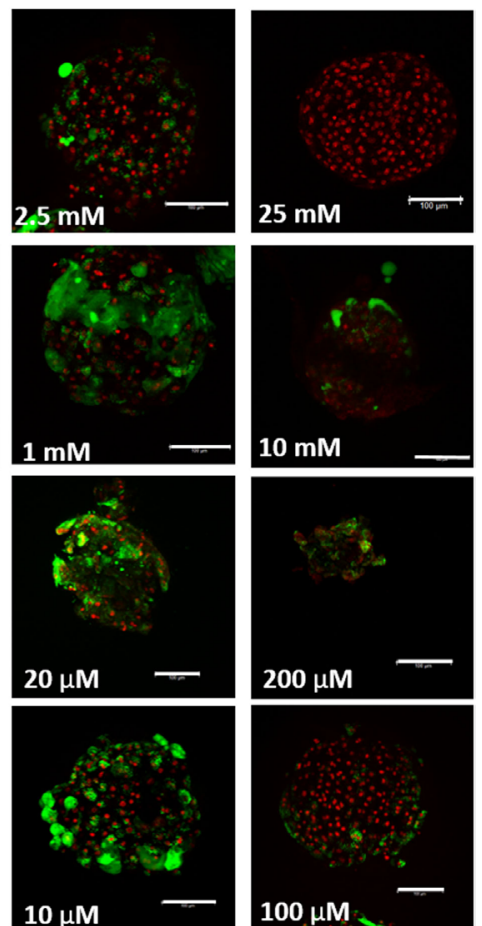

FIGURE 1 | Visual assessment of environmental toxin effects on liver organoids by live/dead assay. The effects of glyphosate, lead, mercury, and thallium on liver organoids using ethidium homodimer dead (red) and calcein AM live (green) staining. Scale bars are equal to $100 \mu \mathrm{m}$.

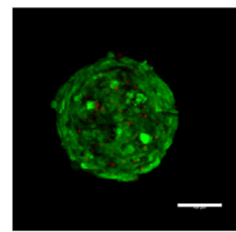

Healthy Cardiac Organoid
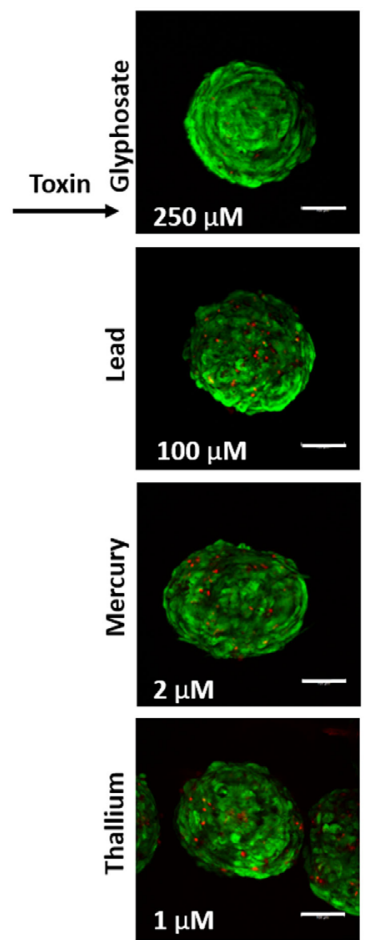
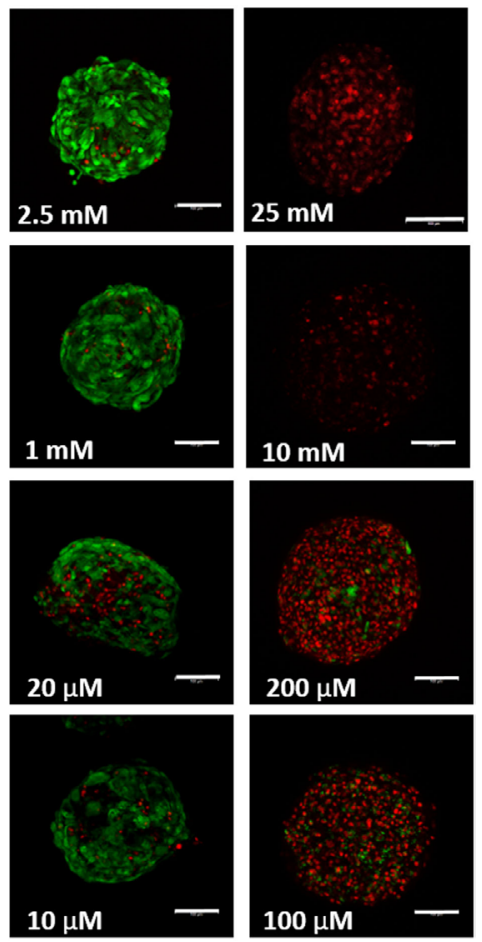

FIGURE 2 | Visual assessment of environmental toxin effects on cardiac organoids by live/dead assay. The effects of glyphosate, lead, mercury, and thallium on cardiac organoids using ethidium homodimer dead (red) and calcein AM live (green) staining. Scale bars are equal to $100 \mu \mathrm{m}$. 


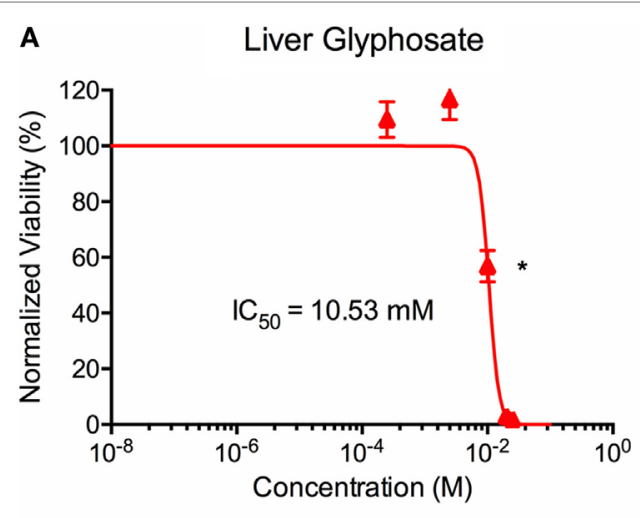

C

Liver Mercury

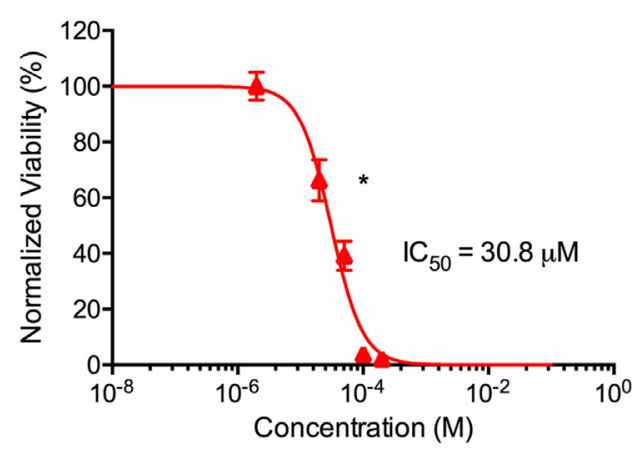

B

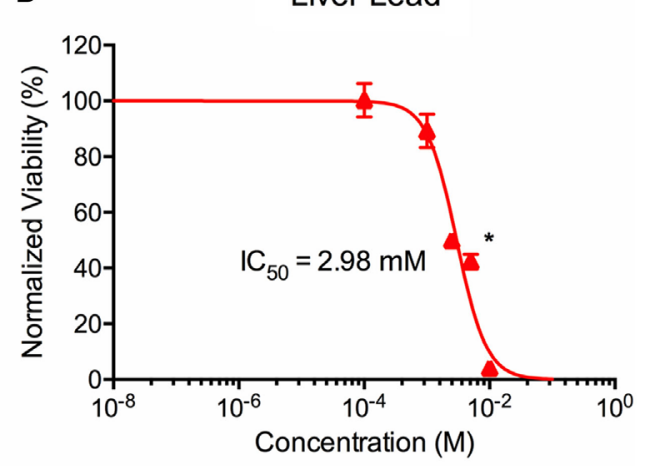

D

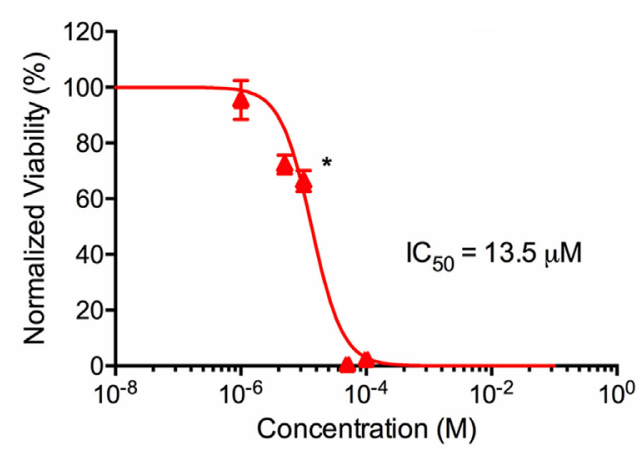

FIGURE 3 | Environmental toxin effects on liver organoid ATP activity. ATP survival curves for liver organoids exposed to glyphosate (A), lead (B), mercury (C), and thallium (D) over the course of two days. Adjusted ATP activity is a comparison of the ATP value of organoids exposed to toxins over the control liver organoids. Statistical significance: ${ }^{*} p<0.01$ with bracket encompassing all doses with this value. IC50 value was determined through calculation of line crossing the IC50 marker.

channel impairment in 2D cardiomyocyte populations and defined as immediate (30 min), short term (1 day), and long term ( 2 days). $p$-values below 0.05 were defined as significant. Glyphosate demonstrated a range of toxicity at doses of $250 \mu \mathrm{M}$ and higher, with beat rates at $250 \mu \mathrm{M}$ slowing on day one among all organoids and two of the three organoids ceasing beat on day 2, although this did not reach a significant $p$-value due to high SD of sample (Figure 5A). At $2.5 \mathrm{mM}, 1$-day toxicity caused two spheroids to cease beating entirely, with one-third showing a $50 \%$ reduction in beat rate; by day 2 all had ceased beating. Lead toxicity presented at $100 \mu \mathrm{M}$ with significant beat reduction at 1 day. $1 \mathrm{mM}$ lead did not display a significant beat reduction at 1 day, but by 2 days showed a complete cessation (Figure 5B). Mercury was highly effective at stopping beat rate over the course of $24 \mathrm{~h}$, with doses of $2 \mu \mathrm{M}$ and above ceasing beating. Of the $2 \mu \mathrm{M}$, one organoid ceased beating on day 1 and began to slowly beat on day 2 , the only organoid in the entire study to do so (Figure 5C). A rise in beat rate was observed at $20 \mu \mathrm{M}$, reflecting a result shown in ATP assay of raised ATP at doses of 10 and $20 \mu \mathrm{M}$ before falling to IC50 value (Figure 4C). Thallium demonstrated toxic effects at all concentrations of $1 \mu \mathrm{M}$ and above, in particular at concentrations of $10 \mu \mathrm{M}$ with severe depressive effects on heart beat at $30 \mathrm{~min}$ and total cessation of all time points at concentration of $100 \mu \mathrm{M}$ (Figure 5D).

\section{DISCUSSION}

While countless environmental toxins exist, and there are many that are pertinent to human health, and many more that require study to understand their potential impacts on human health, we chose several traditional, well-studied toxins to challenge our organoid systems. Our objective was to display the utility of bioengineered 3D in vitro organoids for rapid environmental toxin screening, using multiple widely studied toxins that have been explored thoroughly in animal models and for which toxicity in humans has been also well documented. Specifically, testing began with well-researched heavy metal and pesticide toxins due to the significant amount of past research into each of them, albeit often in 2D cell culture systems. As such, the doses for original testing were gathered from literature as a starting point for our own calculations (28-30). As all have shown toxic effects on multiple organ systems in the body, our system comprising organoids representing multiple tissue types can be utilized to show both general and specific toxicity toward each of the tissue organoids present, encompassing metrics derived from ATP activity assays, LIVE/DEAD-stained organoid images, and physiological heart beat assays. From these tests, we can demonstrate that our organoids begin to show observable physiological effects in a time frame that is generally 

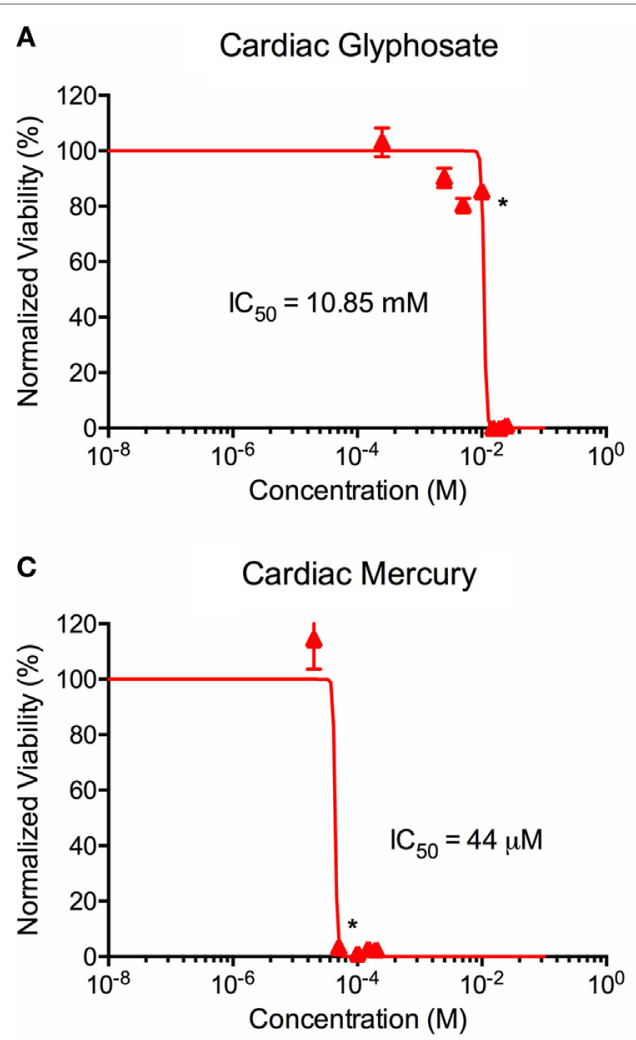

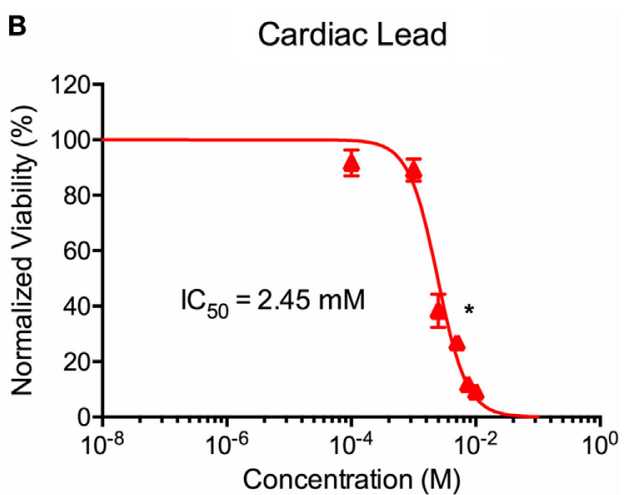

D

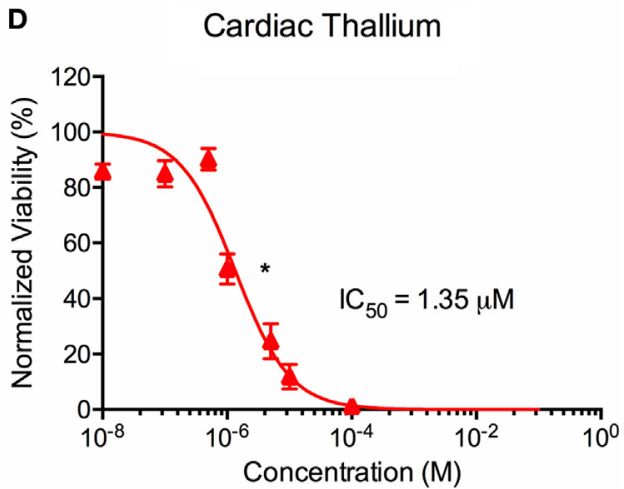

FIGURE 4 | Environmental toxin effects on cardiac organoid ATP activity. Survival curves for cardiac organoids exposed to glyphosate (A), lead (B), mercury (C), and thallium (D) over the course of two days. Adjusted ATP activity is a comparison of the ATP value of organoids exposed to toxins over the control cardiac organoids. Statistical significance: ${ }^{*} p<0.01$ with bracket encompassing all doses with this value. IC50 value was determined through calculation of line crossing the IC50 marker.

faster, and by methods less time intensive and complicated than probing of biochemical markers, as well as being one of the first documented deployments of 3D organoid models for detection of these acute toxicities for environmental toxins. Combining the results of these tests creates a picture of toxicity that demonstrates the value of multiple tests to show the progression of toxicity in our organoids, with the ideal goal being a comparison to those levels found in human blood plasma to show our system effectively mimics human toxicity.

Three well known environmental toxins and a pesticide were selected for testing in both the cardiac and liver model systems: glyphosate, lead, mercury, and thallium. Glyphosate ( $N$-phosphonomethyl glycine) is used as a part of pesticides on crops that have been bred to have resistance to it; however, the chemical is present on crops after harvest. Glyphosate has been found to negatively affect endocrine receptors in the body and is toxic to liver hepatocytes both in vivo and in vitro (31). It has also been potentially linked to a wide range of ailments, including diabetes, cancer, stroke, and Parkinson's disease (15). Lead toxicity manifests itself in a multitude of ways, including increasing free radical oxygen species causing oxidative stress by affecting the creation and efficacy of antioxidants created from glutathione by displacing sulfide groups, decreasing the reduced form and increasing the oxidized form, and causing an increase in reactive oxygen species (ROS) (32). Additionally, lead can also displace other ions with a +2 charge, including $\mathrm{Ca}^{+2}, \mathrm{Mg}^{+2}$, and $\mathrm{Fe}^{+2}$ that are involved in cellular processes and affect both efficiency and create direct and indirect cytotoxicity. Mercury bioaccumulation effects have been well researched in marine life and affect humans through consumption. Its effects on the neurological system are best understood, but it can affect any organ which is exposed through several mechanisms, including binding available thiols, interrupting $\mathrm{Ca}^{2+}$ homeostasis through membrane potential changes, and affecting the creation and stability of several cellular components (33). In cardiac tissue, it can affect myosin ATPase and myocardial force development. Thallium toxicity is most often associated with substitution for $\mathrm{K}^{+}$ions by cellular membranes due to similar charge and the negative effects this has on the $\mathrm{Na} / \mathrm{K}$ pump $(34,35)$. Further research has also shown that thallium can directly affect membrane integrity in multiple organelles, including mitochondria, and bind open sulfyhydrol sites in enzymes (36-38). After its accidental discovery, thallium was used as a pesticide and rodenticide as well as a medical treatment of various ailments until it was banned in the US due to risk of accidental poisoning (39).

Our experiments displayed lead toxicity in both cardiac and liver organoids with an ATP IC50 of 2.45 and $2.98 \mathrm{mM}$, respectively, and a significant reduction of heartbeat at 2 days for $100 \mu \mathrm{M}$. Lead exposure typically occurs through either ingestion or inhalation and sources of exposure to humans are numerous 


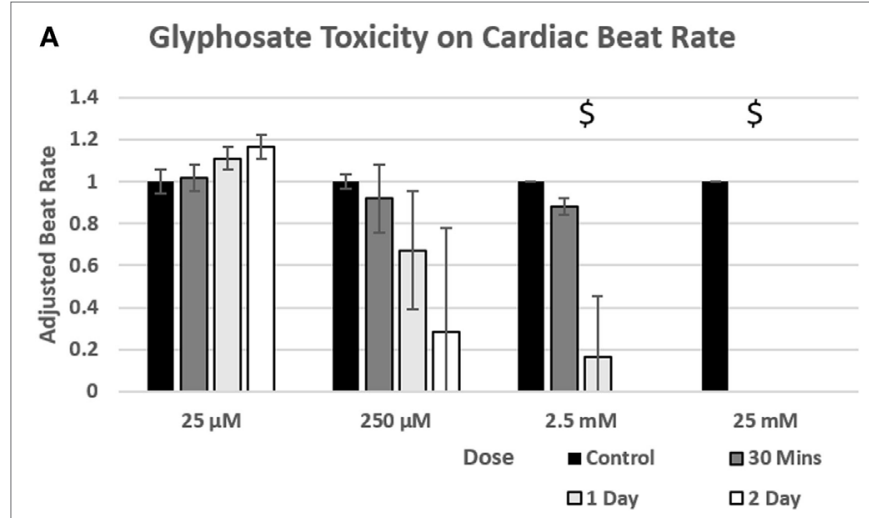

C

Mercury Toxicity on Cardiac Beat Rate

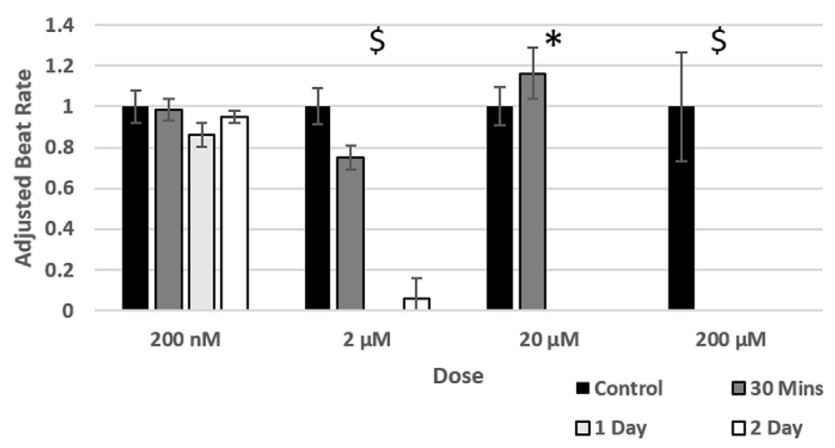

B Lead Toxicity on Cardiac Beat Rate

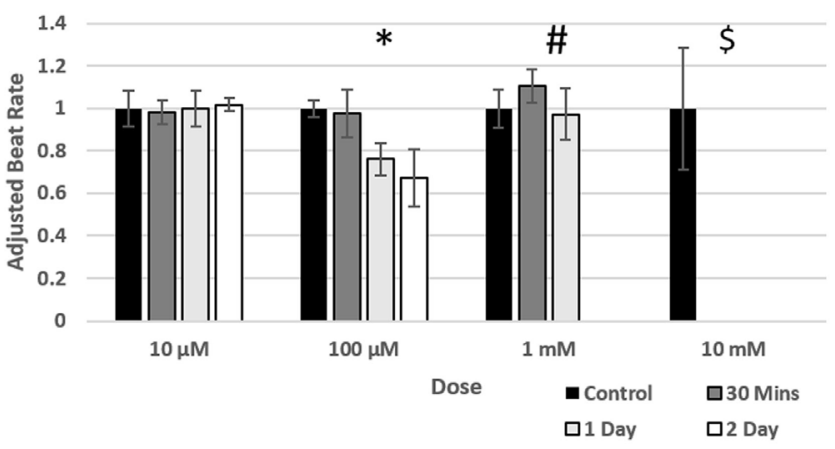

D Thallium Toxicity on Cardiac Beat Rate

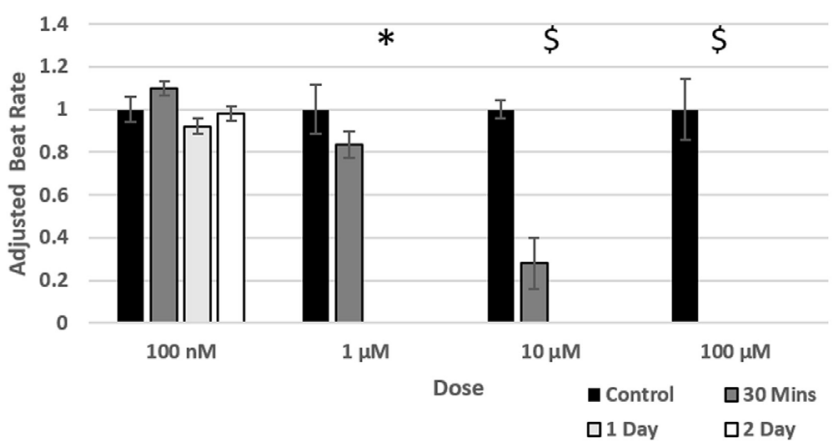

FIGURE 5 | Environmental toxin influence on cardiac organoid beating kinetics. Figure 4 demonstrates the effect of glyphosate (A), lead (B), mercury (C), and thallium (D) on cardiac organoid beat rate. All values $(n=3)$ were taken over $20 \mathrm{~s}$ videos and multiplied by three to find per minute. The adjusted rate is calculated by taking average value of each condition and dividing over the control average. A $T$-test was performed to determine significance between control rates and time after drug was added. Statistical significance: $\# p<0.05$ at 2 days; ${ }^{*} p<0.05$ at 1 day; $\$ p<0.05$ at 30 min.

(40). In Tchounwou et al., an IC50 of $113 \mu \mathrm{M}$ was found for a 2D incubation of HepG2, however, the review of cells present (500,000 per well) is at a significantly higher scale than our experiments. Many other studies have focused on long-term animal studies and physiological differences in cell populations (41-44). Previous research on levels of lead in blood plasma that can lead to fatal outcomes has shown $14.47 \mu \mathrm{M}$ in humans, lower than both our research values and other in vitro models. The probable reason is that lead toxicity often manifests as a prolonged, low exposure systemic poisoning affecting many systems in the patient; it would be unlikely that a person would be exposed to enough lead to cause acute symptoms (45-47). Our research has displayed the system will be able to detect toxicity in this type of exposure if it were to present itself.

Mercury toxicity was displayed at an ATP IC50 of 30.8 and $44 \mu \mathrm{M}$ for liver and cardiac organoids, respectively, significant cell death for both at $20 \mu \mathrm{M}$ in live/dead imaging and ceased heartbeats after 1 day at doses of $2 \mu \mathrm{M}$ and higher. Mercury has been long understood as a toxin with effects on a majority of the systems in the body, including liver and cardiac function $(48,49)$. One study comparing in vitro liver toxicity over 24 hours between several cell types in 2D, including primary human hepatocytes $(106 \mu \mathrm{M})$, primary rat hepatocytes $(726 \mu \mathrm{M})$, the HepG2 cell line $(48 \mu \mathrm{M})$, and the mouse $3 \mathrm{~T} 3$ fibroblast cell line $(8 \mu \mathrm{M})$ to estimated lethal plasma levels in humans $(6.5 \mu \mathrm{M})$ compared well to our calculated values (30.8 and $44 \mu \mathrm{M}$ for liver and cardiac ATP, respectively and $2 \mu \mathrm{M}$ for affecting heart rate) (50).

Thallium was the only toxin with vastly different ATP IC50 doses between cardiac and liver organoids (1.35 and $13.5 \mu \mathrm{M}$, respectively), and stopped heartbeats at 1 day of exposure at $1 \mathrm{nM}$. Similar to mercury, the study comparing in vitro liver toxicity over $24 \mathrm{~h}$ between several cell types in $2 \mathrm{D}$, including primary human hepatocytes $(1,152 \mu \mathrm{M})$, primary rat hepatocytes $(85 \mu \mathrm{M})$, HepG2 cell line $(1,266 \mu \mathrm{M})$, and mouse $3 \mathrm{~T} 3$ fibroblast cell line $(1,527 \mu \mathrm{M})$ to estimated lethal plasma levels in humans $(2.33 \mu \mathrm{M})$ displayed a large difference between the values, suggesting the acute toxicity is not due to hepatic-related mechanisms and may be related to a physiological effect instead of general cellular toxicity (50). While our IC50 for primary liver cells is higher than the lethal patient plasma level in this experiment, the cardiac value for our ATP IC50 $(1.35 \mu \mathrm{M})$ is similar to this value, with the dose affecting heart beat rate at the same dose. A disruption in $\mathrm{K} / \mathrm{Na}$ channel function would affect beat rate significantly and explain the loss of beat rate in relatively low doses tested. Another study on Jurkat cells, immortalized $\mathrm{T}$ lymphocytes, in $2 \mathrm{D}$ determined toxicity at $500 \mu \mathrm{M}$, well above the toxicity calculated by our experiment (51), although histological liver damage was detected in rats exposed to thallium (52). Other studies on the patient plasma levels of 
thallium required for lethality have shown a range from 2.44 to $53.82 \mu \mathrm{M}$. Our toxicity values for both liver and cardiac organoids are encapsulated within this range.

Glyphosate live/dead imaging varied greatly, with the $2.5 \mathrm{mM}$ showing significant cell death in liver organoids and little cell death in cardiac organoids. However, ATP values taken at $10 \mathrm{mM}$ showed a large difference for both the liver and cardiac organoids ( 0.568 and 0.804 , respectively), displaying a more gradual decrease in cell viability for the liver organoids as compared to the cardiac organoids, especially when taking into account the similar IC50 values for the two (10.5 and $10.8 \mathrm{mM}$, respectively), suggesting a variance in toxicity point between the organoids for cardiac, especially when taking into account the differences in beating rate stoppage among the 0.25 and $2.5 \mathrm{mM}$ cardiac organoids. Previous work to determine hepatotoxicity of glyphosate determined an IC50 value of $37.9 \mathrm{mM}$ on a 2D HepG2 model, displaying our $3 \mathrm{D}$ primary system as significantly more sensitive (28). Other experiments utilizing Roundup $@$, the common herbicide utilizing glyphosate as an active ingredient, demonstrate a range of effects on cellular components, ranging from membrane swelling in multiple organelles to increased lysosome numbers and effects on nuclear transcription along with causing hormonal issues in mammalian testing subjects (53-55). Although these effects may be attributable to other ingredients present in the formulation, current opinion remains that continued use of glyphosate in pesticides should be reviewed (53).

By utilizing multiple viability tests, we are able to detect levels of toxicity in multiple assays when exposed to environmental toxins present in the system. Our system is capable of measuring

\section{REFERENCES}

1. Brown MJ, Margolis S. Lead in drinking water and human blood lead levels in the United States. MMWR Suppl (2012) 61(4):1-9.

2. Hanna-Attisha M, LaChance J, Sadler RC, Champney Schnepp A. Elevated blood lead levels in children associated with the flint drinking water crisis: a spatial analysis of risk and public health response. Am J Public Health (2016) 106(2):283-90. doi:10.2105/AJPH.2015.303003

3. Duffus JH. Heavy metals-a meaningless term? Pure Appl Chem (2002) 74(5):793-807. doi:10.1351/pac200274050793

4. Bradl H. Heavy Metals in the Environment: Origin, Interaction and Remediation. (Vol. 6). London: Academic Press (2002).

5. He ZL, Yang XE, Stoffella PJ. Trace elements in agroecosystems and impacts on the environment. J Trace Elem Med Biol (2005) 19(2-3):125-40. doi:10.1016/j. jtemb.2005.02.010

6. Wang S, Shi X. Molecular mechanisms of metal toxicity and carcinogenesis. Mol Cell Biochem (2001) 222(1-2):3-9. doi:10.1023/A:1017918013293

7. Morales ME, Derbes RS, Ade CM, Ortego JC, Stark J, Deininger PL, et al. Heavy metal exposure influences double strand break DNA repair outcomes. PLoS One (2016) 11(3):e0151367. doi:10.1371/journal.pone.0151367

8. Karabelas AJ, Plakas KV, Solomou ES, Drossou V, Sarigiannis DA. Impact of European legislation on marketed pesticides - a view from the standpoint of health impact assessment studies. Environ Int (2009) 35(7):1096-107. doi:10.1016/j.envint.2009.06.011

9. Damalas CA, Eleftherohorinos IG. Pesticide exposure, safety issues, and risk assessment indicators. Int J Environ Res Public Health (2011) 8(5):1402-19. doi:10.3390/ijerph8051402

10. Dawson AH, Eddleston M, Senarathna L, Mohamed F, Gawarammana I, Bowe SJ, et al. Acute human lethal toxicity of agricultural pesticides: a prospective cohort study. PLoS Med (2010) 7(10):e1000357. doi:10.1371/journal. pmed. 1000357 the acute effects on both liver and cardiac 3D organoids and would be easily adaptable to any newly developed organoid, newly discovered toxins, or extended time length. Additionally, it would be straightforward to add additional test protocols, as we have employed in other drug interactions studies (24), to create a more complete picture of toxicity on our representative human organoids. Importantly, organoid platforms such as these, which are 3D, derived from human cells, and exhibit high levels of functionality and physiologically accurate responses to external stimuli, offer a powerful technology that can be deployed for environmental toxin screening, as well as other applications, such as drug development, diagnostics, and personalized medicine.

\section{AUTHOR CONTRIBUTIONS}

SF, MD, TS, and AS designed the experiments. SF performed the majority of organoid toxicity studies. MD performed all confocal microscopy. CB generated the liver and cardiac organoids. SF, TS, SS, AA, and AS evaluated the data and interpreted the results. SF, $\mathrm{MD}, \mathrm{SS}, \mathrm{AA}$, and AS wrote and edited the manuscript.

\section{FUNDING}

The authors gratefully acknowledge funding by the Defense Threat Reduction Agency (DTRA) under Space and Naval Warfare Systems Center Pacific (SSC PACIFIC) Contract No. N660113-C-2027. The publication of this material does not constitute approval by the government of the findings or conclusions herein.

11. Collotta M, Bertazzi PA, Bollati V. Epigenetics and pesticides. Toxicology (2013) 307:35-41. doi:10.1016/j.tox.2013.01.017

12. Mostafalou S, Abdollahi M. Pesticides and human chronic diseases: evidences, mechanisms, and perspectives. Toxicol Appl Pharmacol (2013) 268(2):157-77. doi:10.1016/j.taap.2013.01.025

13. McKinlay R, Plant JA, Bell JN, Voulvoulis N. Endocrine disrupting pesticides: implications for risk assessment. Environ Int (2008) 34(2):168-83. doi:10.1016/j.envint.2007.07.013

14. Aktar MW, Sengupta D, Chowdhury A. Impact of pesticides use in agriculture: their benefits and hazards. Interdiscip Toxicol (2009) 2(1):1-12. doi:10.2478/ v10102-009-0001-7

15. Nicolopoulou-Stamati P, Maipas S, Kotampasi C, Stamatis P, Hens L. Chemical pesticides and human health: the urgent need for a new concept in agriculture. Front Public Health (2016) 4:148. doi:10.3389/fpubh.2016.00148

16. Smith AS, Long CJ, Berry BJ, McAleer C, Stancescu M, Molnar P, et al. Microphysiological systems and low-cost microfluidic platform with analytics. Stem Cell Res Ther (2013) 4(Suppl 1):S9. doi:10.1186/scrt370

17. Benam KH, Dauth S, Hassell B, Herland A, Jain A, Jang KJ, et al. Engineered in vitro disease models. Annu Rev Pathol (2015) 10:195-262. doi:10.1146/ annurev-pathol-012414-040418

18. Bhattacharya S, Zhang Q, Carmichael PL, Boekelheide K, Andersen ME. Toxicity testing in the 21 century: defining new risk assessment approaches based on perturbation of intracellular toxicity pathways. PLoS One (2011) 6(6):e20887. doi:10.1371/journal.pone.0020887

19. Kunz-Schughart LA, Freyer JP, Hofstaedter F, Ebner R. The use of 3-D cultures for high-throughput screening: the multicellular spheroid model. J Biomol Screen (2004) 9(4):273-85. doi:10.1177/1087057104265040

20. Drewitz M, Helbling M, Fried N, Bieri M, Moritz W, Lichtenberg J, et al. Towards automated production and drug sensitivity testing using scaffold-free spherical tumor microtissues. Biotechnol J (2011) 6(12):1488-96. doi:10.1002/ biot. 201100290 
21. Ho WJ, Pham EA, Kim JW, Ng CW, Kim JH, Kamei DT, et al. Incorporation of multicellular spheroids into 3-D polymeric scaffolds provides an improved tumor model for screening anticancer drugs. Cancer Sci (2010) 101(12):263743. doi:10.1111/j.1349-7006.2010.01723.x

22. Skardal A, Devarasetty M, Rodman C, Atala A, Soker S. Liver-tumor hybrid organoids for modeling tumor growth and drug response in vitro. Ann Biomed Eng (2015) 43(10):2361-73. doi:10.1007/s10439-015-1298-3

23. Skardal A, Devarasetty M, Forsythe S, Atala A, Soker S. A reductionist metastasis-on-a-chip platform for in vitro tumor progression modeling and drug screening. Biotechnol Bioeng (2016) 113(9):2020-32. doi:10.1002/bit.25950

24. Skardal A, Murphy SV, Devarasetty M, Mead I, Kang HW, Seol YJ, et al. Multitissue interactions in an integrated three-tissue organ-on-a-chip platform. Sci Rep (2017) 7:8837. doi:10.1038/s41598-017-08879-x

25. Devarasetty M, Forsythe S, Shupe TD, Soker S, Bishop CE, Atala A, et al. Optical tracking and digital quantification of beating behavior in bioengineered cardiac organoids. Biosensors (2017) 7(3):E24. doi:10.3390/bios7030024

26. Skardal A, Devarasetty M, Kang HW, Mead I, Bishop C, Shupe T, et al. A hydrogel bioink toolkit for mimicking native tissue biochemical and mechanical properties in bioprinted tissue constructs. Acta Biomater (2015) 25:24-34. doi:10.1016/j.actbio.2015.07.030

27. Skardal A, Devarasetty M, Kang HW, Seol YJ, Forsythe SD, Bishop C, et al. Bioprinting cellularized constructs using a tissue-specific hydrogel bioink. J Vis Exp (2016) 110:e53606. doi:10.3791/53606

28. Gasnier C, Dumont C, Benachour N, Clair E, Chagnon MC, Seralini GE. Glyphosate-based herbicides are toxic and endocrine disruptors in human cell lines. Toxicology (2009) 262(3):184-91. doi:10.1016/j.tox.2009.06.006

29. Malatesta M, Perdoni F, Santin G, Battistelli S, Muller S, Biggiogera M. Hepatoma tissue culture (HTC) cells as a model for investigating the effects of low concentrations of herbicide on cell structure and function. Toxicol In Vitro (2008) 22(8):1853-60. doi:10.1016/j.tiv.2008.09.006

30. Zierold K. Heavy metal cytotoxicity studied by electron probe X-ray microanalysis of cultured rat hepatocytes. Toxicol In Vitro (2000) 14(6):557-63. doi:10.1016/S0887-2333(00)00049-7

31. Bradberry SM, Proudfoot AT, Vale JA. Glyphosate poisoning. Toxicol Rev (2004) 23(3):159-67. doi:10.2165/00139709-200423030-00003

32. Jaishankar M, Tseten T, Anbalagan N, Mathew BB, Beeregowda KN. Toxicity, mechanism and health effects of some heavy metals. Interdiscip Toxicol (2014) 7(2):60-72. doi:10.2478/intox-2014-0009

33. Fernandes Azevedo B, Barros Furieri L, Pecanha FM, Wiggers GA, Frizera Vassallo P, Ronacher Simoes M, et al. Toxic effects of mercury on the cardiovascular and central nervous systems. JBiomed Biotechnol (2012) 2012:949048. doi:10.1155/2012/949048

34. Galvan-Arzate S, Santamaria A. Thallium toxicity. Toxicol Lett (1998) 99(1):1-13. doi:10.1016/S0378-4274(98)00126-X

35. Douglas KT, Bunni MA, Baindur SR. Thallium in biochemistry. Int J Biochem (1990) 22(5):429-38. doi:10.1016/0020-711X(90)90254-Z

36. Mulkey JP, Oehme FW. A review of thallium toxicity. Vet Hum Toxicol (1993) 35(5):445-53.

37. WoodsJS, FowlerBA. Alteration ofhepatocellularstructureandfunction bythallium chloride: ultrastructural, morphometric, and biochemical studies. Toxicol Appl Pharmacol (1986) 83(2):218-29. doi:10.1016/0041-008X(86)90299-1

38. Korotkov SM, Lapin AV. Thallium induces opening of the mitochondrial permeability transition pore in the inner membrane of rat liver mitochondria. Dokl Biochem Biophys (2003) 392:247-52. doi:10.1023/A:1026182511897

39. Andersen O. Clinical evidence and therapeutic indications in neurotoxicology, exemplified by thallotoxicosis. Acta Neurol Scand Suppl (1984) 100:185-92.

40. Needleman H. Lead poisoning. Annu Rev Med (2004) 55:209-22. doi:10.1146/ annurev.med.55.091902.103653

41. Tchounwou PB, Yedjou CG, Foxx DN, Ishaque AB, Shen E. Lead-induced cytotoxicity and transcriptional activation of stress genes in human liver carcinoma (HepG2) cells. Mol Cell Biochem (2004) 255(1-2):161-70. doi:10.1023/B:MCBI.0000007272.46923.12

42. Gillis BS, Arbieva Z, Gavin IM. Analysis of lead toxicity in human cells. BMC Genomics (2012) 13:344. doi:10.1186/1471-2164-13-344

43. Zhu ZW, Yang RL, Dong GJ, Zhao ZY. Study on the neurotoxic effects of low-level lead exposure in rats. JZhejiang Univ Sci B (2005) 6(7):686-92. doi:10.1631/jzus.2005.B0686

44. Walsh CT, Ryden EB. The effect of chronic ingestion of lead on gastrointestinal transit in rats. Toxicol Appl Pharmacol (1984) 75(3):485-95. doi:10.1016/0041-008X(84)90185-6

45. Wani AL, Ara A, Usmani JA. Lead toxicity: a review. Interdiscip Toxicol (2015) 8(2):55-64. doi:10.1515/intox-2015-0009

46. Lanphear BP, Hornung R, Khoury J, Yolton K, Baghurst P, Bellinger DC, et al. Low-level environmental lead exposure and children's intellectual function: an international pooled analysis. Environ Health Perspect (2005) 113(7):894-9. doi:10.1289/ehp.7688

47. Flora G, Gupta D, Tiwari A. Toxicity of lead: a review with recent updates. Interdiscip Toxicol (2012) 5(2):47-58. doi:10.2478/v10102-012-0009-2

48. Genchi G, Sinicropi MS, Carocci A, Lauria G, Catalano A. Mercury exposure and heart diseases. Int J Environ Res Public Health (2017) 14(1):74. doi:10.3390/ ijerph14010074

49. Cave M, Appana S, Patel M, Falkner KC, McClain CJ, Brock G. Polychlorinated biphenyls, lead, and mercury are associated with liver disease in American adults: NHANES 2003-2004. Environ Health Perspect (2010) 118(12):1735-42. doi:10.1289/ehp.1002720

50. Ponsoda X, Jover R, Nunez C, Royo M, Castell JV, GomezLechon MJ. Evaluation of the cytotoxicity of 10 chemicals in human and rat hepatocytes and in cell lines: correlation between in vitro data and human lethal concentration. Toxicol In Vitro (1995) 9(6):959-66. doi:10.1016/0887-2333(95)00053-4

51. Bragadin M, Toninello A, Bindoli A, Rigobello MP, Canton M. Thallium induces apoptosis in Jurkat cells. Ann N Y Acad Sci (2003) 1010:283-91. doi:10.1196/annals.1299.049

52. Leung KM, Ooi VE. Studies on thallium toxicity, its tissue distribution and histopathological effects in rats. Chemosphere (2000) 41(1-2):155-9. doi:10.1016/S0045-6535(99)00404-X

53. Myers JP, Antoniou MN, Blumberg B, Carroll L, Colborn T, Everett LG, et al. Concerns over use of glyphosate-based herbicides and risks associated with exposures: a consensus statement. Environ Health (2016) 15:19. doi:10.1186/ s12940-016-0117-0

54. Peixoto F. Comparative effects of the roundup and glyphosate on mitochondrial oxidative phosphorylation. Chemosphere (2005) 61(8):1115-22. doi:10.1016/j.chemosphere.2005.03.044

55. Clair E, Mesnage R, Travert C, Seralini GE. A glyphosate-based herbicide induces necrosis and apoptosis in mature rat testicular cells in vitro, and testosterone decrease at lower levels. Toxicol In Vitro (2012) 26(2):269-79. doi:10.1016/j.tiv.2011.12.009

Conflict of Interest Statement: The authors declare that the research was conducted in the absence of any commercial or financial relationships that could be construed as a potential conflict of interest.

Copyright (c) 2018 Forsythe, Devarasetty, Shupe, Bishop, Atala, Soker and Skardal. This is an open-access article distributed under the terms of the Creative Commons Attribution License (CC BY). The use, distribution or reproduction in other forums is permitted, provided the original author(s) and the copyright owner are credited and that the original publication in this journal is cited, in accordance with accepted academic practice. No use, distribution or reproduction is permitted which does not comply with these terms. 